\title{
Do Fintech and Cryptocurrency Initiatives Make Banks Less Special?
}

\author{
Sebastian Schich* \\ Organisation for Economic Co-operation and Development (OECD) \\ E-mail: sebastian.schich@ oecd.org
}

Received: September 27, 2019 Accepted: October 22, 2019 Published: October 29, 2019

doi:10.5296/ber.v9i4.15720

URL: https://doi.org/10.5296/ber.v9i4.15720

\begin{abstract}
Banks as a group have traditionally been considered "special" in the sense of meriting the full set of provisions of the financial safety net. The specific motivations for that view have evolved over time, although it owes more to a specific combination of economic functions performed as opposed to any particular function. These functions include offering transaction accounts redeemable in cash on demand, providing liquidity, and serving as conduits for payments and monetary policy transmission. Recent developments suggest however that almost all of the individual economic functions performed by banks can in fact be provided in unbundled form by Fintech initiatives, in some cases more rapidly, at lower fees, and via more streamlined digital interfaces. One important exception remains monetary policy transmission. For the performance of this function, policy makers and central bankers have reserved a privileged role for banks. A radical departure from the current fractional reserve system would be required to unbundle that function and separate money from the banking system, and some private cryptocurrencies have been proposed with the explicit intent to change the nature of money. So far, the present article concludes such initiatives remain marginal, so that banks as a group remain "special". This observation owes much to the fact that central banks rely on the capacity of the banking system to create money and provide the economy with adequate liquidity and, despite occasional financial crises, have concluded that the efficiency of the current system outweighs the associated costs.
\end{abstract}

Keywords: Banks, Financial stability, Financial safety net, FinTech, Cryptocurrencies

* The author is a Principal Economist in the OECD Directorate of Financial and Enterprise Affairs. The report has been presented to and discussed by the OECD Committee on Financial Markets at its meeting in April 2019. It has benefitted from the discussions at that meeting and from the comments made by delegates at the meeting and subsequently in written form, as well as a presentation made at that meeting by Giuseppe Grande. Stephen Lumpkin also provided comments. All remaining errors are the author's only. The opinions expressed and arguments employed herein do not necessarily reflect the official views of the Organisation or of the governments of its member countries. 


\section{Introduction}

This report focuses on the functions typically associated with deposit-taking banks and asks whether the advent of Fintech initiatives that replicate some of these functions makes banks less "special". This "specialness" is seen as warranting the full set of protections afforded by the financial safety net; it refers to banks as a group, that is, to the banking system, but not necessarily to each individual bank. The present report draws on the framework developed by Lumpkin and Schich (2019), which suggests these functions include offering transaction accounts redeemable in cash on demand, providing liquidity, and serving as conduits for payments and monetary policy transmission. The present report also extends the framework to include private cryptocurrencies as part of the Fintech initiatives considered. It uses the extended framework to address one of the two questions raised in the initial framework report, which is to what extent Fintech makes banks less special?

Fintech is defined as the combination of finance and technology to provide financial services and, for the present analysis, the focus is on digital financial services similar to those provided by deposit-taking banks (e.g. provision of transaction accounts, payment services, and lending, etc.) as well as the so-called cryptocurrencies. ${ }^{1}$ These could be private or public in nature. Public cryptocurrencies, typically referred to as digital central bank currencies, have recently been the subject of considerable research among central banks and public international institutions as regards their potential role as new forms of "money". Helpful recent reviews of that literature include Bech and Garratt (2017). The present report primarily focuses on private cryptocurrencies, which, incidentally, have been proposed with the explicit intent to change the nature of money, if not to disintermediate banks.

Fintech is not a new phenomenon but the pace of change has quickened more recently, especially as digital infrastructure has been further deployed and as devices like smart phones provide ever-present access to financial services. The number of Fintech initiatives has multiplied over the past few years, with some of them scaling up fast. These initiatives provide financial services in innovative ways and several of them overlap with the set of services traditionally offered by banks. Essentially, the financial services traditionally offered by banks are unbundled and offered either separately or in rebundled form by these new Fintech initiatives, often in more convenient form and at lower cost. Against the background of these developments, the quote attributed to Bill Gates that "banking is necessary, banks are not" seems more relevant today than ever. To the extent that the monetary system evolves to encompass private or public cryptocurrencies also serving as money, the "specialness" of banks is likely to be substantially eroded.

Section 2 reviews how the justifications for bank "specialness" among financial intermediaries have evolved over time. Section 3 explains the role of the financial safety net for banks. Section 4 considers how digital banking initiatives enter this relationship. Section 5 addresses the question to what extent banks remain "special" despite such initiatives. Section 6 extends the analysis to private cryptocurrencies. Section 7 concludes.

\footnotetext{
${ }^{1}$ The word cryptocurrency is used here for easy reference, but not to suggest that the various so-called cryptocurrency initiatives have succeeded in representing currency.
} 


\section{Considerations Regarding the "Specialness" of Banks}

Discussions of the "specialness" of banks typically revolve around the economic functions that banks provide, although views about the relevance of each specific economic function and the mix of functions that might make banks "special" have evolved over time. To understand the different views, it is helpful to review the fundamental economic functions performed by a financial system.

A primary role of the financial system is allocative. A well-functioning financial system is widely understood to have an important allocative role of helping the economy to fully exploit its growth potential by ensuring that viable investment opportunities receive necessary funding at appropriate costs. This process involves i) producing information about potential investments and alternatives for allocating capital, ii) monitoring investments to ensure adherence to the contracts that consumers and investors hold, and iii) mobilising and pooling savings. Performing these three functions entails a range of different activities to meet the needs of those looking to finance projects and those looking to invest excess funds, as the needs and preferences of these two groups may not coincide in terms of time horizons, risk tolerances, expected returns/costs, or as regards particular contract dimensions.

Defining the primary function of the financial system as resource allocation, Merton (1995) distinguishes altogether six secondary core functions, derived from that primary function. These are shown in the first column of Table 1. The table also links these functions to the core functions of banks (in the second column). At the macroeconomic level, the various products and services that banks provide can ultimately be linked to the management by banks of two sets of cash flows - loans and deposits. As highlighted by the third column, taking deposits and lending are the two activities that relate to the performance of the various core functions of banks.

Despite the agreed importance of banking functions, how exactly to include banking activity in macroeconomic models has remained somewhat controversial. What seems clear, however, is that the simple approach of considering banks as mere passive conduits has been largely dismissed as unhelpful. In fact, standard macroeconomic textbooks have long recognized that banks are special; for example, to quote Blanchard and Fisher (1989, p. 478): "The notion that there is something about banks that makes them 'special' is a recurrent theme". However, there is no agreement in the literature as to what exactly makes banks special and related views have evolved over time.

One view is that collecting small denomination, withdrawable-on-demand deposits, and transforming them into larger denomination, longer-term loans, or using them in the mediation of various other credit, market and duration risks gives rise to two of the key activities of banks - liquidity provision and maturity transformation. In fact, bank credit can help to bridge the gap between short-term funds and longer-term investment positions. Moreover, banks have invested in credit risk assessment, monitoring and contract enforcement, the combination of which is referred to as the delegated-monitoring function of banks (e.g. Calomiris, 1997). It is not clear, however, to what extent this monitoring function is unique to banks. Conceptual analysis has addressed the issue of whether banks might be 
more efficient monitors than lending platforms (e.g., for a review, see Havrylchyk, 2018), but only the passing of a full credit cycle will allow one to draw firm empirically-backed conclusions in this regard.

Banks can provide credit even in stressful situations, drawing initially on their links to other banks to access available liquidity through the interbank market and the reverse repurchase market, or through the issuance of large certificates of deposits. These exchanges of liquidity among banks allow the direct and contingent credit facilities provided by banks to serve as a backstop source of liquidity on which other, including non-bank-intermediated, credit markets depend.

When market stress is more generalised and affects the banking sector itself, banks can rely on their "exclusive" direct links to central banks and other provisions of the financial safety net. As a result of this privileged access, banks have been the conduits of "quasi risk-free liquidity" to financial and payment systems, where the qualification "quasi" refers to the observation that any financial safety net is ultimately only as strong as the public authorities backing it.

Table 1. Relationship between core functions of banks and the financial system

\begin{tabular}{|c|c|c|}
\hline Core functions of the financial system & Core functions of banks & Related activity \\
\hline $\begin{array}{l}\text { Provides a payment system for the } \\
\text { exchange of goods and services }\end{array}$ & $\begin{array}{l}\text { Transaction accounts (redeemable in } \\
\text { cash on demand and at par) }\end{array}$ & Deposit taking \\
\hline \multirow{2}{*}{$\begin{array}{l}\text { Provides a mechanism for the pooling of funds to } \\
\text { undertake large-scale indivisible enterprise }\end{array}$} & Transaction accounts & Deposit taking \\
\hline & Delegated monitor & Lending \\
\hline \multirow{3}{*}{$\begin{array}{l}\text { Allows to transfer economic resources through } \\
\text { time and across locations }\end{array}$} & Transaction accounts & Deposit taking \\
\hline & Providing liquidity services & Lending \\
\hline & Delegated monitor & Lending \\
\hline \multirow[t]{3}{*}{ Facilitates the management of risk } & Transaction accounts & Deposit taking \\
\hline & Providing liquidity services & Lending \\
\hline & Delegated monitor & Lending \\
\hline \multirow{2}{*}{$\begin{array}{l}\text { Provides price information that helps } \\
\text { co-ordinate decentralized decision-making }\end{array}$} & Delegated monitor & Lending \\
\hline & $\begin{array}{l}\text { Conduits for Monetary policy } \\
\text { transmission }\end{array}$ & Lending \\
\hline Provides ways to deal with asymmetric information & Delegated monitor & Lending \\
\hline
\end{tabular}

Note: Extension from Merton (1995).

This privileged access also brings another social benefit. It allows the public to treat bank liabilities as stores of safe purchasing power, which makes deposits a source of stable funding. As deposits are backed only partly by reserves under the prevailing fractional reserve system, banks in effect create money as a by-product of their lending activities. ${ }^{2}$

\footnotetext{
2 That money creation function applies to the banking system as a whole, although some have argued that it applies to each individual entity. For example, Werner (2014) observes that in the process of making credit available in the borrower's bank account, the lending bank does not mechanically transfer the money away from other internal or external accounts (nor does the bank always check whether such transfers were feasible at all), but instead "invents" the funds by crediting the borrowers' account with a deposit. Given that no such deposit had taken place, a bank "can individually create money out of nothing".
} 
If not completely misallocated, under normal circumstances, the economy benefits from this money creation and, more generally, from the maturity transformation between banks' risky assets and their "safe" liabilities. In times of stress, however, fears on the part of depositors about the safety of their funds can result in "runs", whereby a large number of depositors attempt to withdraw their funds at the same time. Banks would typically not be able to satisfy these collective demands, as they usually will have entered into binding liquidity commitments by on-lending funds at longer maturities. The resulting sudden mismatch between assets and liabilities is at the core of the fragility problem of banks.

To handle such unanticipated demands for outflows, banks hold buffer stocks of liquid assets. Unfortunately, they bear all the costs of the buffer, but do not capture all of the social benefits and, hence, may not always have incentives to hold sufficient amounts. In the event a bank's liquidity buffer falls short, it is forced to find liquidity elsewhere, either by borrowing in the interbank market or by selling assets. Either option can prove elusive. For example, selling assets in a stressed market environment to meet short-term liquidity demands risks getting prices well below the assets' intrinsic quality, which can worsen rather than ameliorate an institution's problems, on account of the implied hit to capital for assets marked to market.

Moreover, both fire sales of assets and the failure of the bank can have spillover effects to other financial institutions and the economy as a whole, which results at least in part from accompanying contractions in credit availability. It is this externality that creates a role for policy. Most governments provide support for the liquidity and sometimes arguably even the solvency of banks to reduce the likelihood of panic and the spread of the difficulties to the real economy. Functioning under this support structure has been the privileged position of banks.

\section{Banks and the Financial Safety net}

\subsection{Financial Stability Concerns and the Financial Safety Net}

Banks have not always operated under the support structure afforded by the financial safety net (FSN) and views regarding the benefits of government intervention to ensure financial stability have evolved. A marked change occurred in the wake of the Great Depression (Schwartz, 1992; Calomiris and Wheelock, 1997) when financial regulatory policy reflected the view that maintaining the health of individual institutions was a prerequisite for maintaining the health of the financial system as a whole. Because financial institutions are more closely interlinked than are firms in other sectors, the risk of contagion - the potential for failure of an individual bank to lead to the failure of other financial institutions - is one of the more distinctive features of the financial sector. It is at the core of public policy interventions and the need to regulate the system. Contagion could result from banks' direct linkages in the interbank markets or payment systems or indirectly from the interdependency of their portfolios. Reducing systemic risk and preserving a stable financial system are principal motivations for prudential regulation and safety net arrangements in the form of deposit insurance and the lender of last resort.

Deposit taking and maturity transformation are the two types of activities of banks that are 
linked to most of their own and the financial system's core functions. Maturity transformation (i.e., taking deposits and on-lending them) is necessary to ensure that the system has an adequate supply of liquid funds, and the current system of fractional reserve banking fundamentally relies on banks producing adequate supplies of money. It is the performance of these activities that explains why the provisions of the FSN protect banks. While the system is considered efficient by most policy makers, it is nonetheless recognized that the system is not accident-free and requires a financial safety net to deal with the risk of a systemic crisis.

The lender of last resort, strictly speaking, relates to the provision of liquidity by the central bank to individual banks in distress. Although there is a long-standing debate in the academic literature as well as in policy circles about the optimal form and the precise role of the lender of last resort, there seems to be a general consensus that, at least under normal market conditions, this instrument should not be used to deal with individual bank insolvencies. Rather, the central bank should provide liquidity to banks that are temporarily illiquid, but solvent, which should help avoid a widespread use of public money and thus limit the moral hazard problem implicit in any insurance or guarantee scheme.

The deposit insurance function primarily protects depositors, while the lender-of-last-resort function protects primarily the system (although in doing so it also protects depositors as well as other users of the financial system). Conceptually, if complete, deposit insurance ensures that depositors will be paid and, thus, eliminates the incentives for runs. In practice, however, such insurance is by design not complete in order to limit moral hazard.

Both the lender-of-last-resort function and the deposit insurance function are meant to avoid "runs". Any financial intermediary, and not just commercial banks, performing maturity transformation is subject to potential "runs". This insight has motivated the considerable attention spent by the Financial Stability Board on monitoring developments and potential financial vulnerabilities in so-called non-bank or market-based financial intermediation, as will be discussed in the next section. While "runs" on insolvent financial firms can be efficient or not, runs on illiquid but solvent firms are always inefficient as long as there are transaction costs involved in the resolution of a failing financial firm. In fact, a market failure arises because of asymmetric information and the initial normative function of the lender of last resort was to provide support to solvent but illiquid banks in the face of liquidity shocks associated with their traditional business model of taking deposits withdrawable on demand and lending out the funds over longer-term fixed periods.

There are, however, some important caveats to the provision of both the lender-of-last-resort and the deposit insurance functions. First, access to these provisions of the financial safety net are counterbalanced by additional restrictions imposed by a bank regulatory framework, implementation of and adherence to which is enforced by supervision. The regulatory and supervisory functions are the quid-pro-quo for access to the deposit insurance and lender-of-last-resort functions. Second, out of concern that the safety net does not become overextended, policy makers have not only limited the extent of deposit coverage but have also limited deposit taking to a limited set of institutions. The set includes commercial banks and, in principle, entities licensed to provide related commercial-bank-like functions. 


\section{Mll Macrothink}

Business and Economic Research

ISSN 2162-4860

2019, Vol. 9, No. 4

The recent global financial crisis served notice that the dimensions of the regulatory framework cannot focus solely on microprudential concerns, but must also entail a macroprudential approach. To be effective in maintaining financial stability, it is not sufficient for policy to focus on the safety and soundness of individual institutions. Rather, it is also necessary to consider the level and distribution of risk at the aggregate level, given the close interconnections among banks through interbank claims, derivatives transactions, and similar portfolio compositions. These interlinkages are not stable over time, but change as part of the dynamic nature of the financial system. New and emerging financial technologies are among the factors transforming the nature and extent of these interlinkages.

Another important role of the financial safety net is that it ensures a smooth and efficient exit of insolvent firms that do not have a viable business model. The global financial crisis has confirmed the view that failure resolution proceedings for banks need to be different from standard insolvency proceedings. In particular, bank insolvency regimes should ensure that creditors are treated fairly and predictably and that the financial firm's asset value is maximised in the interest of creditors, while preserving the stability of the financial system.

The crisis also made it clear that the speed of resolution is a key issue in restoring calm and that traditional corporate insolvency rules are ineffective when it comes to ensuring that failure resolution of a large financial firm does not precipitate a contagious collapse of the system. Hence, while resolution frameworks for banks were in the past linked mainly to deposit insurance, more recently, a wider set of arrangements has been adopted to ensure smooth and efficient exit of large financial firms.

One new element concerns the guarantor-of-last-resort function, which was introduced de facto as part of the financial safety net as part of the policy response to the global financial crisis. The attribute "de facto" reflects the view that the guarantor function was always more or less present, given that many governments have stepped in to provide guarantees when faced with systemic banking problems. Providing that function in this crisis consisted of assurance to financial market participants that the safety of the liabilities (and sometimes even assets) of financial intermediaries would be guaranteed by public authorities to avoid a potential "run" on banks by counterparties and creditors. Policy makers in some jurisdictions announced that bank deposits would be protected without limits, Ministries of Finance set up various funds to protect specific types of financial firm liabilities (and in some cases also assets), and central banks gave assurance that central bank liquidity would always be ample). A stylized view of the financial safety net is provided in Figure 1.

In discussing the initial policy response to the global financial crisis, the OECD Committee on Financial Markets (CMF) opined that the addition of the guarantor-of-last-resort function was perhaps necessary to avoid a worst-case outcome but noted that this response was not costless. The costs include the perception that some banks are so "special" that their debt is implicitly insured by public authorities, which means they are unlikely to be forced to exit the market, at least not in an uncontrolled way. Current financial regulatory reform explicitly aims to reign in such expectations, although recent estimates of the value of implicit guarantees suggests the deed has not yet been accomplished (Schich, 2018). 


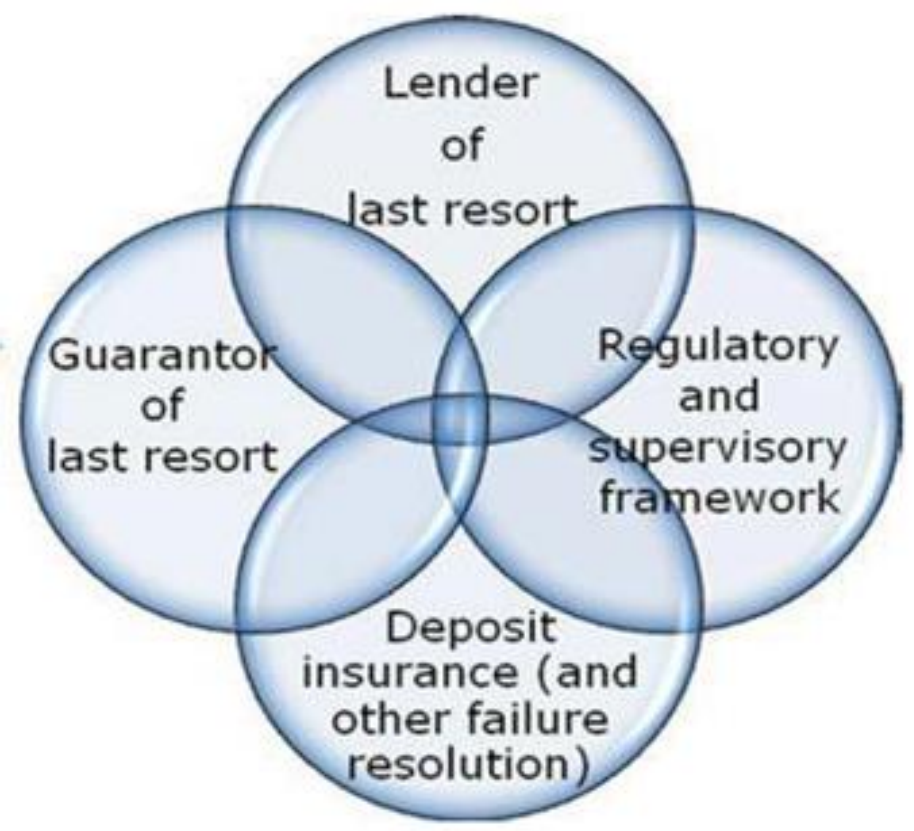

Figure 1. Financial safety net provisions

Note: Traditionally, the financial safety net was defined as consisting of a lender-of-last-resort and a deposit insurance function (which could include special bank failure resolution regimes) and, as a counterbalance for the privileges associated with these functions, a regulatory and supervisory framework. The policy response to the recent global financial crisis consisted effectively of making available the government-supported function of guarantor of last resort in more explicit form, thus changing the design of the financial safety net. Governments and central banks provided a wide range of explicit guarantees for the liabilities and sometimes assets of financial institutions and in particular banks. As a result of these interventions, a fourth function has been added to the traditional financial safety net in more explicit form.

Source: Schich (2013).

\subsection{Changes in the Institutional Perimeter of the Financial Safety Net}

At the peak of the global financial crisis, the perimeter of the FSN was extended to encompass institutions beyond the banking sector. Subsequently, a declared policy objective has been to clarify that so-called shadow banking activities are excluded from the perimeter of the FSN. ${ }^{3}$ Shadow banking, defined as financial intermediation that involves credit, maturity and liquidity transformation (Adrian and Ashcraft, 2016), is (meant to be) excluded from the provisions of the financial safety net given that it is neither regulated nor supervised as banks are. The latter are given access to safety provisions such as the lender-of-last-resort function, but, in return, they are also exposed to constraining regulation and capital requirements. Supervision of banks is meant not only to ensure compliance but also to assess and ensure banks' prudent behaviour over and above regulation to limit the effects of moral

\footnotetext{
3 In 2018, FSB discussions concluded that FSB communications would use the term "nonbank financial intermediation" instead of "shadow banking", but for simplicity and conformity with common references, the present discussion continues to refer to shadow banking activities.
} 


\section{MInstitute ${ }_{\text {Ink }}^{\text {Macrothink }}$}

Business and Economic Research

ISSN 2162-4860

2019, Vol. 9, No. 4

hazard. Shadow banking is not facing the same constraints, however, which is why they should be excluded from the FSN. ${ }^{4}$ In fact, some shadow banking products have been explicitly designed to allow the financial intermediary to avoid such constraints.

Banks are special at least to some extent because they have been made "special" by central banks, mainly on account of their role as the main conduits through which monetary policy actions are transmitted to the real economy. Even so, as Huertas (2018) notes, some change is taking place. For example, central banks have broadened the perimeter of entities that form part of the monetary policy transmission channel. In particular, via quantitative easing policies and other measures, central banks have broadened the group of counterparties they use beyond banks. Thus, at least along this dimension, banks have become somewhat less special. A normalisation in this regard is widely expected, however. Thus, while the set of entities that serve as central bank counterparties for quantitative easing policies was enlarged to include non-banks, that status does not seem to be firmly entrenched, however. In fact, CMF discussions concluded that banks as institutions are unique in their non-interrupted role as conduits for monetary policy transmission.

Traditionally, central banks mainly, if not exclusively, used banks to transmit monetary policy impulses to the economy. The policy rate set by central banks has either been the rate at which the central bank lends to banks or the rate at which banks can borrow central bank money in the market. Central banks have conducted monetary policy by either directly lending to banks or by conducting open market operations with them. As a result of these measures, the level of central bank reserves at banks is altered, which in turn affects the banks' capacity to lend to finance economic activity.

Under quantitative easing policies, central banks began to interact with securities markets and investors in a more direct way. Central banks determine the eligibility of assets as collateral for lending and repurchase activity and also directly acquire a range of assets via open market operations. In the process, central bank decisions on the range of securities eligible as collateral or central bank open market operations became an additional monetary policy tool, the effects of which go beyond the banking sector. In fact, the choice of the new apparatus of monetary policy tools results, in part, from the view that the relatively weak economic recovery, especially in Europe, even after a decade following the global financial crisis owes primarily to the improper functioning of the traditional monetary policy transmission channel.

\section{Developments in Fintech Activities}

\subsection{Fintechs Unbundling and Rebundling the Services Provided by Banks}

Finance has been digitalising for some decades now, although the pace of change has quickened during recent years. The conversion of information from analogue to digital forms, along with the development of application systems and platforms, is changing the nature of assets that generate value, how ownership is imparted and where value is generated. This development fosters changes in the structure and operation of markets, allows so-called

\footnotetext{
4 This argumentation is based on an ex ante perspective and, as the global financial crisis has demonstrated, considerations ex post might differ and a time-inconsistency problem arise.
} 
ecosystems to be formed and, built on the connectivity of the Internet, ultimately encourages changes in the nature of relationships, both social and economic. In particular, the ability to code, store and share information in a standardised form lowers a broad range of transactions costs and allows to limit asymmetric information issues and provides a framework for interaction and the development of customised relationships.

The retail financial services segment is often characterised by a long-term relationship between the bank and the retail customer, facilitated among other things by the face-to-face nature of relationships between banks and customers afforded by a branch network, but certainly also reflecting switching costs and customer inertia. The problem with the branch-based network of commercial banks is that they tend to be very costly to maintain. To make them cost-effective requires distributing a sufficient volume or value of products and services through them to cover all costs, including the staff and branch costs of mobilising and administering the products. The benefits are that branch networks can support many different product lines (scale economies), facilitating the cross-selling of new products to existing customers, and the bundle of products from a single supplier might be less costly than purchasing them from multiple sellers (scope economies). The retail financial services segment encompasses transactions services such as payments, lending, savings and safekeeping, investments, insurance, and financial advice, combinations of which commercial banks have traditionally offered as bundles.

The digital transformation of finance changes the characteristics of economies of scale and scope. In particular, digital financial products may have high initial fixed costs associated with licensing, software and application development, but little if any marginal costs. This feature, combined with global distribution potential via the Internet, can enable digital providers and platforms to achieve scale quickly and with very few employees or tangible assets. As regards economies of scope, just as high switching costs can cause retail customers of traditional banks to become locked-in with their existing service provider, digital applications can be developed so that customers become accustomed to the look and feel of particular applications, which then can be used to provide additional products and services, once the necessary comfort level has been reached.

For banks, products and services on the asset side need to be priced to cover all operating costs, including staff and branch costs, costs of loan-loss provisions, and the cost of capital. While the total revenues of the spectrum of products and services offered by banks might exceed total costs, on a component basis, the results can be quite different. Importantly, revenues from products and services for which the bank has some pricing power may be used to subsidise those from more competitive market segments where margins are lower. Payment services are considered a "cash cow" for banks, which explains why this source of revenues is the primary target of Fintech initiatives, also facilitated by open banking initiatives.

These initiatives are effectively unbundling commercial banking services and products, and they provide i) some of these services separately, ii) in rebundled form together with some other services and iii) together with some new services or at a minimum in a manner that is 
more convenient for customers. As noted by Mark Carney, Governor of the Bank of England, "FinTech's true promise springs from its potential to unbundle banking into its core functions of: settling payments, performing maturity transformation, sharing risk and allocating capital..."

In fact, Fintech initiatives are engaged in many of the same activities as commercial banks, including a few that make banks special under the FSN. Table 2 shows two major exceptions between the functions that make banks special under the FSN and those performed by digital banking initiatives. They are maturity transformation and serving as conduits for the transmission of monetary policy, although experimentation regarding the design of cryptocurrencies seem to challenge the role of banks as unique providers of the former economic function.

Table 2. Functions of banks and Fintech initiatives

\begin{tabular}{|l|l|}
\hline Functions that make banks "special" under the FSN & Functions of various FinTech initiatives \\
\hline Safekeeping (deposit taking) & Safekeeping (eW); Deposit taking (DB) \\
\hline $\begin{array}{l}\text { Transaction accounts (redeemable in cash on demand } \\
\text { at par) }\end{array}$ & Transaction accounts (DB, eW) \\
\hline Liquidity provision, including through lending & $\begin{array}{l}\text { Liquidity provision, incl. through lending (DB, eW, } \\
\text { P2P, CC) }\end{array}$ \\
\hline Maturity transformation & $\begin{array}{l}\text { Facilitating the exchange of payments (DB, eW, CC, } \\
\text { API) }\end{array}$ \\
\hline Clearing and settling payments & \\
\hline $\begin{array}{l}\text { Serving as conduits for transmission of monetary } \\
\text { policy }\end{array}$ & \\
\hline
\end{tabular}

Notes: DB denotes digital bank, eW denotes electronic wallet, P2P denotes P2P lending and crowdfunding, CC denotes (private) cryptocurrencies, and API stands for application programming interface.

Source: Adapted from Lumpkin and Schich (2019).

\subsection{Fintech Efforts to Scale Up and Bank Strategic Responses}

Many Fintech initiatives appear to have ample start-up and venture capital funding and are engaged in a quest to scale up and increase their market share. For example, by early 2019, altogether 39 Fintech companies were identified by CBInsights (2019) as having a private market valuation exceeding USD one billion (a threshold beyond which companies are referred to in the jargon as "unicorns"). In Europe, the list included Transferwise, Revolut, and Monzo from the United Kingdom, and N26 from Germany and Klarna from Sweden. The list grew to 39 in 2018, as 16 companies became "unicorns".

The digital transformation of other sectors has featured a similar core strategy, whereby ample digital capacity and the perceived advantages of scale encourage and (ultimately often) justify bearing short-term losses while scaling up to gain market share and future profitability. For some digital banking initiatives, especially in the payments area, low pricing takes the form of the "no fee" model. As a result, customers become conditioned to expect low prices as more start-ups enter and adopt the new pricing model, and this development in turn forces incumbents to follow suit (Beaudemoulin et al., 2018). 


\section{Ml Macrothink}

Business and Economic Research

ISSN 2162-4860

2019, Vol. 9, No. 4

In the case of lending platforms, many are still making losses, as they have not yet achieved a sufficient scale to cover their fixed costs. Achieving scale is thus a key aim for many platforms and it seems to require the involvement of institutional investors. In the longer term, a no-fee model for an entity offering a limited product range is a questionable revenue proposition, which means new initiatives must eventually develop and deploy priced services, adopt a different revenue model, or be absorbed into the ecosystem of a multi-product entity that allows for cross-subsidisation.

Increasing competition in the area of payments is putting downward pressure on margins from payments services, and this outcome is one of the main intended consequences of new regulatory so-called open banking initiatives. As a result, banks do expect to see a continued reduction in fees - and even an expansion of the no-cost model - on payment means (cash, bank cards, checks, transfers and direct debits), brokerage services for unit-linked contracts or collective investment scheme units, and more generally, on everyday banking services.

That said, there are client segments in retail banking that are not especially price sensitive. Most savers who select a liquid account are more interested in greater access to their savings and the safety of their funds than in higher interest earnings. Hence, while some financial products may, at a basic level, be recognised as the same sort of product, they are not generally speaking treated as perfect substitutes by the typical retail customer. In particular, given the nature of the entities providing them, these products may or may not be covered by the provisions of the FSN. A stylised illustration is provided in Figure 2, highlighting that some initiatives seem to be lying outside the perimeter of the publicly supported FSN.

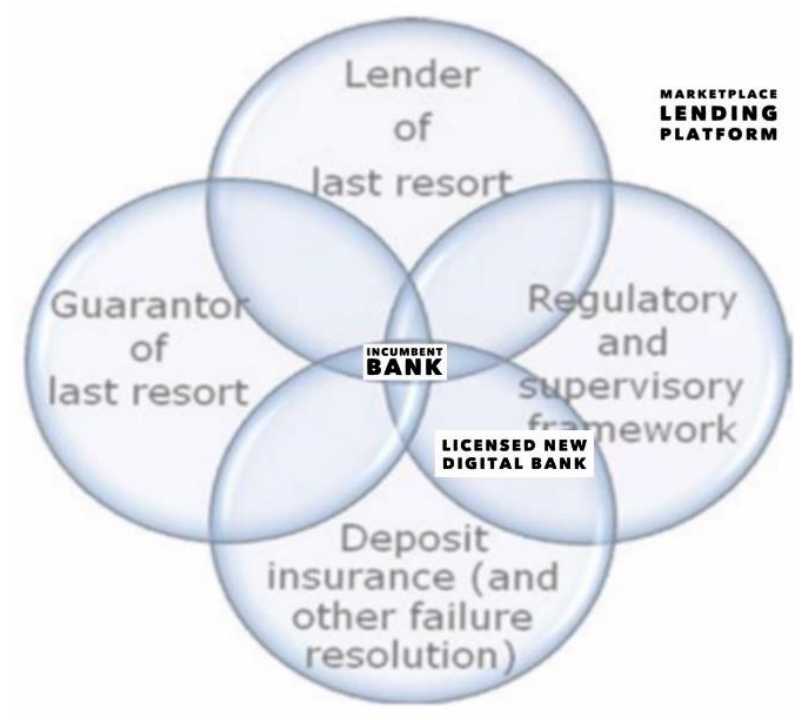

L'CENSEP CRYPTO

Figure 2. The FSN, incumbent banks and Fintech, and cryptocurrency initiatives: Entities

Source: Author's assessment 


\section{Al Macrothink}

Business and Economic Research

ISSN 2162-4860

2019, Vol. 9, No. 4

Consolidation has been a common outcome in markets subject to excess capacity and some new digital banks have been acquired by incumbent providers or by other entities seeking to expand their scale or make their own inroads. Other initiatives attempt to remain independent by relying on new revenue streams, obtained for example from exploiting their data or earning commissions on customer referrals. A report by the Financial Stability Board and the Committee on the Global Financial System (FSB/CGFS, 2017) distinguishes between four types of interactions between incumbent banks and new Fintech initiatives, which are: i) for banks to provide specific operational services to the platforms, such as payment, settlement and custodial services; ii) for banks to originate loans on the behalf of lending platforms; iii) partnership agreements, which could include the referral of denied customer; and iv) direct investments. In fact, incumbent banks might acquire Fintech entities for strategic reasons and to complement their own portfolio of services or for providing similar services at lower costs. Another motivation might simply be "If you can't beat them, buy them." As a result, new institutional links are being created.

Yet another linkage between incumbent banks and Fintech initiatives that might not be readily apparent is that bank accounts are often still part of the intermediation process, especially as regards many digital payment methods. In this context, one structure that is becoming a more common approach in the digital transformation of banking services is the use of application programming interfaces (APIs) to link banks' own structures to innovative digital products developed by third-party developers. APIs allow for the automated transfer of funds from one account to another, and the use of APIs has been clearly encouraged by regulatory initiatives such as the European Payments Services Directive (PSD2) and other open banking initiatives. Many banks have decided to use APIs independently of such initiatives to allow them to enable third parties to develop and implement applications that run on top of their own infrastructure and link to their own client base. The exact nature of the embedded protocol varies depending on the particular application and Figure 3 provides some examples. The figure also highlights that banks are given access to all provision of the financial safety net, while Fintech initiatives are being given access to parts of it, either directly or indirectly. Whether the latter pay an adequate premium for this access is an important question identified by Lumpkin and Schich (2019); addressing it is beyond the scope of the present report. 


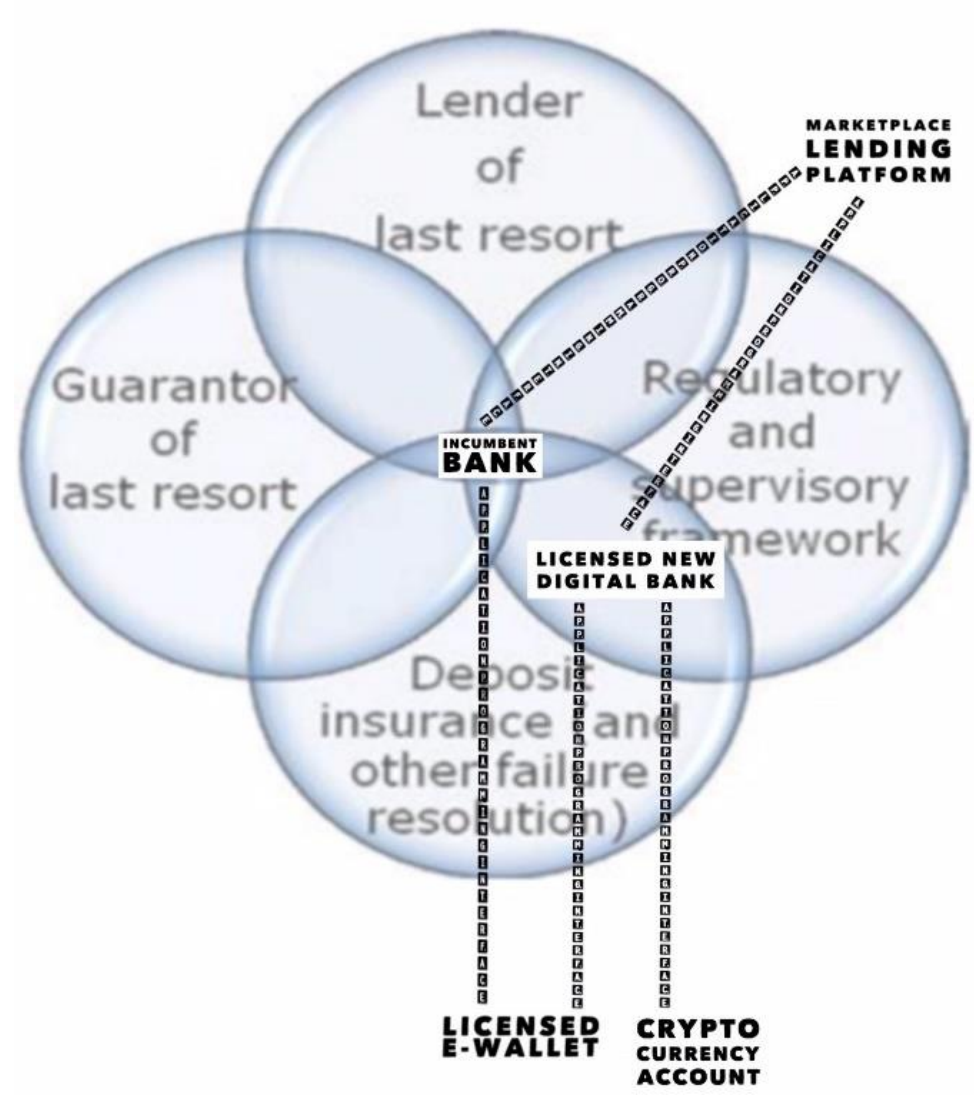

Figure 3. The FSN, incumbent banks and Fintech, and cryptocurrency initiatives:

Linkages created through application programming interfaces

Source: Author's assessment.

\section{Performance by Banks of Core Economic Functions, "Specialness" and the FSN}

Policy makers appear to have made a conscious choice to allow the potential efficiency gains from the faster, easier-to-use, always accessible digital format to be realised, which implies that the regulatory response to digital banking initiatives should not be overly constraining. Taken as a group, Fintech initiatives overlap many of the activities and functions that banks provide, including some functions deemed to make banks "special" under the provisions of the financial safety net. Thus, one might ask whether the institutional "specialness" of banks will prevail as Fintech initiatives affect a growing number of bank functions and start to scale.

To address that question, it is useful to recall the discussion in the framework report on bank specialness (Lumpkin and Schich, 2019). The report suggests that a useful starting point is the answer given in 1982 by E. Gerald Corrigan (Corrigan, 1982), then President of the Federal Reserve Bank of Minneapolis, in response to the question "what makes banks special and what is the public purpose of banking".

The answer given by Corrigan was that it is the combination of liquidity provision, maturity 
transformation, and serving as the conduit for monetary policy that merits the provision of a FSN centred on banks. These characteristics have to be jointly present for a bank to be considered "special". Building on that definition, discussions by the CMF concluded that banks are "special" not because of any specific economic function that they perform, but rather as a result of the combination of different functions that they perform, which include:

- First, taking deposits that are withdrawable on demand and at par.

- Second, providing liquidity to other entities, thus, given the first function, engaging in maturity transformation.

- Third, acting as conduit for the payment system and monetary policy transmission.

The initial answer by Corrigan was provided against the backdrop of the innovation of money market mutual funds that promised interest payments while offering either immediate withdrawal or the ability to effect transactions by using payable-through drafts. Even though Corrigan (Corrigan, 2000), revisiting his earlier essay of 1982, recognised that the earlier answer was not strictly transferable to the situation in 2000, he confirmed its main elements. It continues to be a particularly helpful reference, as the current wave of innovation bears some similarities to that earlier episode. In that context, discussions by the CMF in April 2019 on another topic, which is that of market-based financial intermediation, encouraged the Committee to consider the systemic dimensions of the shift from bank-based to market-based financial intermediation. Moreover, the suggestion was to investigate the interactions between the two forms of intermediation and the financial safety net, adopting a framework that focuses on economic functions as shown in Figure 4.

As long as banks issue transaction accounts that regulation foresees to be payable on demand and at par and readily transferable to a third party, bank lending raises special issues. In particular, extending loans, loan commitments and standby letters of credit implies that banks undertake maturity transformation. The thus created direct and contingent credit facilities are the foundation upon which credit markets depend for their existence, including or perhaps in particular in situations of financial stress. Banks can provide such credit even in times of stress through their relations with other banks, and when stress generalises to large parts of the banking sector, through their access to central bank lending and other provisions of the financial safety net. 


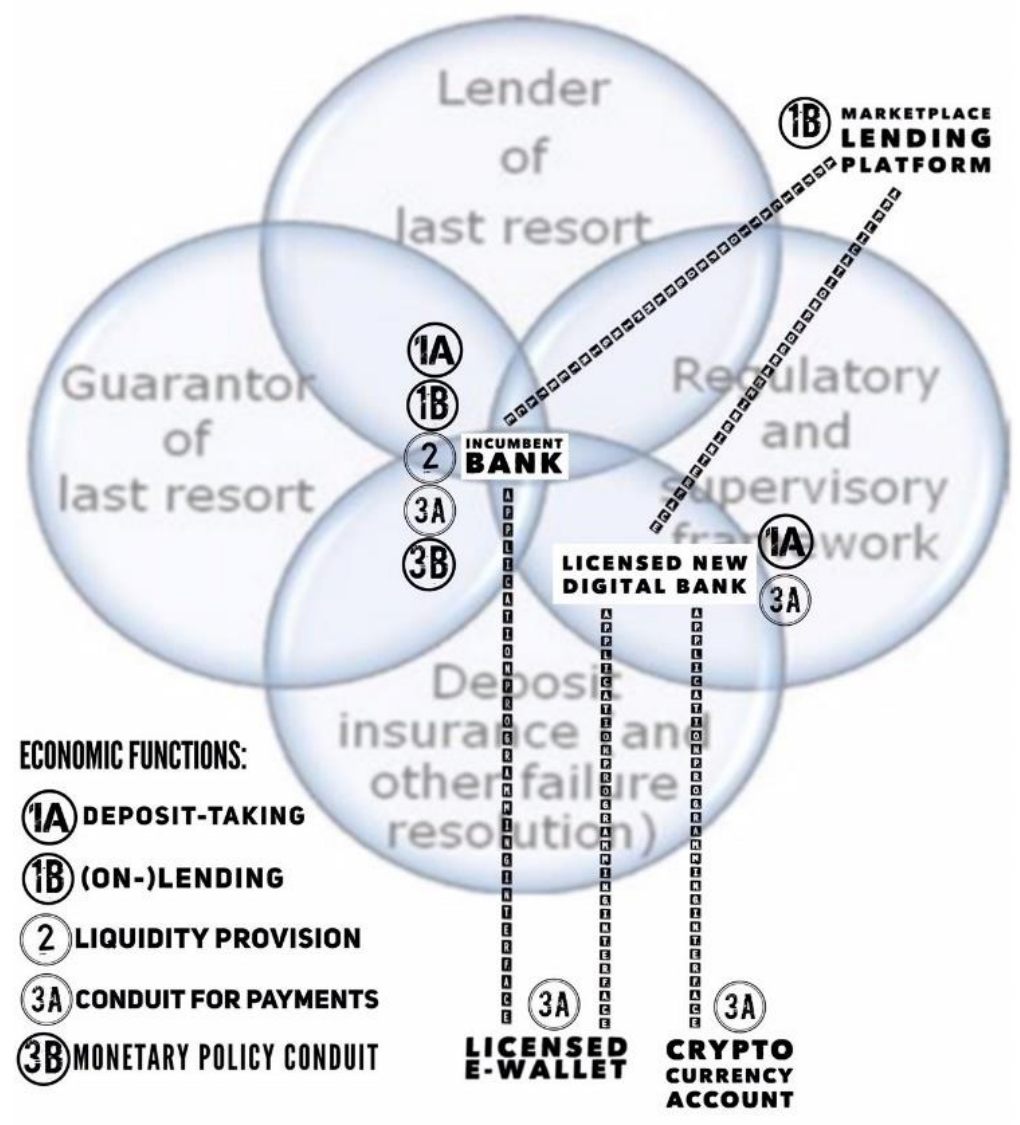

Figure 4. The FSN, incumbent banks and Fintech, and cryptocurrency initiatives: Linkages and economic functions

Source: Author's assessment.

Given banks' privileged access to the central bank balance sheet, typically via lending facilities, as well as the observation that they are subject to reserve requirements, banks are in a unique position to be the "transmission belt" through which central bank actions affect financial market and credit conditions. Moreover, the reserves in the banking system provide the balances that permit the orderly end-of-day settlement of wholesale payment transactions.

These core bank functions are sufficiently cloaked with a public interest to warrant public provision of a safety net, so that there is a concomitant public interest in ensuring these institutions' safety and soundness to ensure that risks to the explicit or implied government safety nets that protect banks are minimised. In fact, CMF discussions concluded that an important justification for the existence of the financial safety net is to ensure the integrity of the monetary policy transmission mechanism.

That said, there does seem to be an element of circularity in the earlier justification for why banks are special. On the one hand, identifying banks as special qualifies them for access to the financial safety net. On the other, for banks to effectively perform some of their core characteristic economic functions requires them to have access to the provisions of the 
financial safety net, access that, in turn, makes them special (see Figure 5).

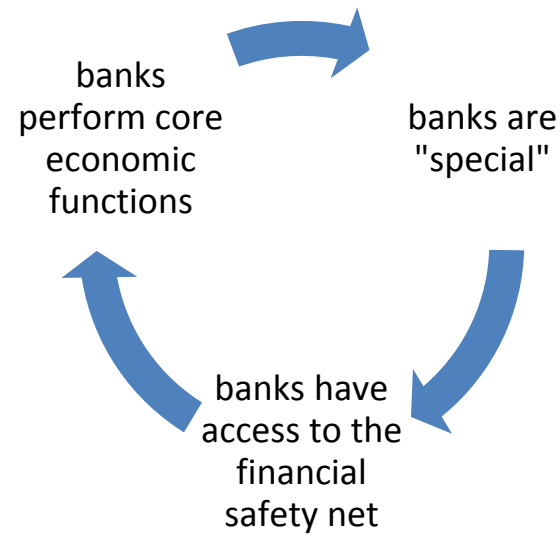

Figure 5. Linkages between bank core functions, "specialness" and access to the FSN Source: Lumpkin and Schich (2019).

\section{Would Private Cryptocurrencies Make Banks Less Special?}

\subsection{Cryptocurrencies to Challenge the "Specialness" of Banks?}

What makes banks, as a group, special depends at least in part on public policies and legislation, which change over time and are adapted to changes in the institutional provision of banking-like financial services. Banks are currently given a privileged role as conduits for the payment system, involving (public) fiat currencies. In fact, the "specialness" of banks depends crucially on decisions of the central banking community to support a system of intermediation based largely on the provision of central bank money to and withdrawal of central bank money from commercial banks. The sight deposits that commercial banks hold with the central bank are particularly important in this context, as they are used for the settlement of payment transactions.

The privileged role of banks as conduits for the payment system is being challenged to some extent, including as a result of open banking initiatives undertaken by public authorities. Open banking initiatives attempt to foster competition and innovation by allowing third parties to gain access to banks payment infrastructure and related customer data, provided the customer explicitly agrees to the data sharing. Open banking initiatives have focused on payment services, especially retail, as these are considered inefficient and fairly costly. While it is too early to draw firm conclusions on the effect of these initiatives, there is evidence that prices for retail payment services including in particular those involving cross-border transactions have declined and the quality of services improved. Thus, to some extent, the capacity of Fintech initiatives to unbundle services might affect banks' provision of payment services. One specific economic function that seems to have escaped the before-mentioned unbundling logic is that of monetary policy transmission.

To the extent that the monetary and payment system evolves to embrace private or public 
cryptocurrencies serving as "money", the "specialness" of banks could be further eroded. In fact, cryptocurrencies compete with banks directly in providing a means of payment. They enable peer-to-peer exchanges of monetary value without a trusted intermediary between counterparties that may not have enduring transactional relationships. But these assets are not considered legal tender in most jurisdictions. Were they to become more widely accepted (as they become considered as a reliable store of value), however, there is at least the potential that they could pose a challenge to banks in their role in the payments system.

To what extent private cryptoassets are a more cost-efficient way of facilitating payments than banks remains to be seen, however. The initial proposition of private cryptocurrency initiatives involves decentralisation through the use of distributed ledgers. The latter involve a duplication (or multiplication) of efforts that is more costly than maintaining a single ledger. Also, maintaining the entire history of transactions instead of recording current balances requires a much larger storage space. Some cryptocurrencies are more efficient than others and require less storage space as parts of records can be deleted, although a key security characteristic of cryptocurrencies is the fact that an immutable record is decentrally stored. Smith and Kumar (2018) conclude that it is not clear that the alleged cost advantage of cryptocurrencies in some dimensions is sufficiently large to be able to out-compete the traditional e-payments system.

By contrast, cryptocurrencies currently do not pretend to challenge banks in terms of their liquidity-provision function. They also do not challenge banks in the domain of on-lending funds received. Transactions involving cryptocurrencies are typically verified and completed only if the sender has sufficient cryptocurrencies to effectuate the transaction. In the standard blockchain approach, account balances must be non-negative. Efforts have been made, however, to alleviate that constraint. For example, Ripple has introduced the concept of I-owe-you (IOU), whereby a public address grants ex-ante specified credit limits to other specified public addresses. Another possibility is afforded by smart contracts, which use computer protocols to ensure the automatic execution of certain features of a contract, although such automatisation is challenged by the complexity of potential divergences in interpretations. As a result, some cryptocurrency initiatives foresee using arbitrators or courts to resolve disputes, but such efforts are made more difficult in situations where not all transacting parties are easily identifiable. In fact, the underlying premise of the blockchain technology that is at the heart of private cryptocurrencies is that of pseudo-anonymity. This feature tends to aggravate adverse selection and moral hazard problems present in lending, and might explain why cryptocurrencies are not well-suited to handle credit (Smith and Kumar, 2018).

Private cryptocurrencies, including in particular the most prominent example Bitcoin, have been introduced with the explicit intent to change the nature of money that is being used. Rather than relying on a fractional reserve system involving central and private banks, such initiatives are motivated by attempts to separate money from the banking system. If such efforts were successful, banks would likely become less special. That said, while private cryptocurrencies challenge banks "specialness" in one dimension, they might provide additional justification for it in another dimension (Box 1). 
Just like fiat currency, cryptocurrencies lack any intrinsic value beyond their function as money; they do not have any non-monetary function. Whether and to what extent they can be money depends on how well they function as a medium of exchange, store of value and unit of account. Unlike, for example, gold, which can serve non-monetary functions, fiat currencies and cryptocurrencies rely on the belief that other people will accept them for future transactions, so that they can function as temporary stores of value. Typically, cryptocurrencies are not centrally issued (with the notable exception of central bank digital currency) and not backed by any precious metals or government promises. They thus require trust, just like fiat currencies. In the case of the latter, that trust is provided by the FSN, which is supported by public authorities. Cryptocurrencies other than those issued by the central bank, henceforth referred to as central bank digital currencies (CBDC), are not backed by public authorities, however, at least not directly.

A crucial distinguishing feature of cryptocurrencies as compared to fiat currency is that they cannot be redeemed into fiat currency cash (White, 2015). By contrast, bank deposits are denominated in fiat currency units and the deposit-taking bank promises to redeem bank deposits one-to-one for fiat currency, either at maturity or, in the case of current accounts, on demand. Private cryptocurrencies are however usually denominated in their own units. They might be converted into other cryptocurrencies, tradeable assets, access to products or services at pre-specified rates of exchange, either at fixed rates or as a specific function of other variables. Moreover, cryptocurrencies might also be exchanged against fiat currency on exchanges. That requires however that there is another party that is willing to take the opposite side; the exchange is not backed by legislation.

Box 1. Banks as delegated monitors for AML/TF efforts

Discussions by the OECD Committee on Financial Markets in April 2019 on the "specialness" of banks highlighted yet another justification for such a status: banks as delegated monitors for anti-money-laundering and terrorism-financing efforts. In particular, while not necessarily related to their systemic role, banks might also be considered "special" for their role as delegated monitor for compliance with anti-money-laundering and anti-terrorism-financing (AML/TF) efforts. In fact, since at least the 1970s, banks have been relied on to act as gatekeepers to ensure adherence to AML/TF rules. Clearly, these specific considerations would not seem to justify giving banks access to all aspects of the FSN, although their performance of this function would serve another public interest.

There are recent calls for tighter regulation of exchanges to make them act as the gatekeepers between cryptocurrencies and fiat currencies (He et al., 2016). Deferring to regulation in their own jurisdictions the decisions to deal with cryptoassets and the definition of what constitutes a security, the International Organisation of Securities Commission (IOSCO, 2019) provided for consultation a toolkit to supervise these platforms. IOSCO also provided a list of resources and approaches taken across countries. If regulators were to have these platforms join banks as gatekeepers, the latter would be less "special" as delegated monitors for AML/TF efforts. 


\subsection{The Crucial Role of a Robust Institutional Backing for a Currency}

As regards the capacity of any private cryptocurrency to replace publicly supported monies, a recent report by the Bank for International Settlements (BIS, 2018) is rather sceptical. ${ }^{5}$ Related research identifies some specific challenges inherent in some types of cryptocurrencies. For example, an important aspect of the functioning of Bitcoin is that the seigniorage is recuperated by the decentralized participants that make the system work. Thus, as Bitcoin's block rewards fall to zero, transaction fees alone will not be able to sustain mining expenses, so that it would take more time for Bitcoin payments to become final, unless other new technologies are deployed to speed up payment finality. The fundamental remedy would be to depart from proof-of-work and, instead, use "some form of social co-ordination or institutionalization". Against this background, one conclusion is that "in the digital age too, good money is likely to remain a social construct rather than a purely technological one" (Auer, 2019).

In reviewing the issue of cryptocurrencies becoming money, Landau (2018) observes that all private monies that had existed since the beginning of the 19th Century finally collapsed as a result of crises of confidence during financial or banking crises. Landau also recalls that it is these recurrent crises that led to the creation of the central banks of today, which are in charge of issuing and controlling the central bank money that serves as the base of the current monetary system.

The central bank community and most policy makers consider the current monetary regime to be efficient, in which fiat currency serves as money in the economy. The current system relies, in addition to central banks creating a monetary base, consisting of coins and bills minted or printed by public authorities, on private banks creating a multiple of money. The system is one of fractional reserves as only a fraction of all money in circulation is backed by reserves at the central bank. The rationale for that design is to more efficiently meet the demand of the overall economy for money, as compared to a system relying on the central bank alone. That said, the implied fractional reserve system implies that private banks, especially as a result of the maturity-mismatch taken, are exposed to the risk of sudden and exceptionally large withdrawals of funds. Thus, for the system to be safe, various publicly supported provisions are required, as described in previous sections.

Cryptocurrencies are not a liability of any institution, and therefore do not give rise to the same maturity-mismatch problem as with the current fractional reserve system. By contrast, bank deposits are liabilities of deposit-taking banks, while bank notes are typically interpreted as liabilities of central banks (and they were even backed by gold reserves during certain episodes, e.g. in the United States). Unlike fiat currency balances at deposit-taking

\footnotetext{
5 For that reason, and to avoid conveying some form of public legitimacy to the formers' use as money, recent discussions at the BIS and the FSB tend to refer to the broader category of cryptoassets rather than to cryptocurrencies. In the remainder of the present chapter, the broad term of cryptocurrencies will continue to be used, however, including to describe private initiatives. This reflects a widespread practise and takes into account that some of the cryptocurrencies might acquire some, although not necessarily all, characteristics of fiat currency. Public cryptocurrencies are referred to as central bank central bank digital currencies ("CBDC") rather than public cryptocurrencies ("CBCC"), as in Bech and Garratt (2017).
} 
banks, there is no need for deposit insurance for cryptocurrency balances (Yermack, 2013). The latter cannot be depleted as a result of the failure of a financial institution. That said, fraud or theft can still result in cryptocurrency balances disappearing. Thus, one might suggest that a pure payment system, which is not embedded in a wider monetary system, likely does not require access to the full financial safety net. That said, one needs to acknowledge that pure payment systems are rarely observed in practice.

In the near term, the development of cryptocurrencies is not expected to significantly affect the power of central banks to conduct effective monetary policy in their own fiat currency (Smith and Kumar, 2018). Such a power would diminish, however, with the extent to which cryptocurrencies become routinely used for payment and settlement, as well as a store of value. The capacity by public authorities to achieve macro stabilisation would be adversely affected if a substantial part of the payment system would involve decentralised private cryptocurrencies, the supply of which is independent of the business cycle.

Currency management has a societal value, and stable money is what enables societies to function well, which is why currency management is part of the wider social contract between individuals and the government (Claeys et al., 2018). Similarly, as argued by Borio (2019), the current monetary system could be understood as having money at its core, that is essentially debt in the form of an implicit contract between the individual and society. The former provides something of value to society in return for a token such as money and trusts in being able to use it in the future. This implicit contract, in turn is underpinned by the role of the state, which issues laws and formalizes the implicit contract, including by providing the FSN. The question is whether any private initiatives, including various forms of cryptocurrencies, will ever obtain a similar efficiency and certainty in meeting the demand for liquidity that the current monetary system offers.

In fact, a fundamental difference between private tokens on the one hand and the current legal currency on the other lies in the issue of trust and the institutions to secure it (Borio, 2019). To see that it is useful to distinguish two forms of trust (Figure 6).

- First, there is trust that others will accept the token as a means of payment and that the transfer will be effective.

- Second, there is trust that the value of the token will be fairly stable in terms of goods and services that it allows one to acquire in the future. In other words, trust that the value of the token will not change very significantly in one or the other direction.

Private cryptocurrencies aim at developing a system that generates trust without having to rely on the state, although their notion of trust can appear to be somewhat narrowly defined and refers only to the first notion of trust defined above. In the case of decentralised private cryptocurrencies relying on distributed ledger technology, the settlement mechanism is direct and not intermediated; in fact, the transaction is settled as soon as enough system participants agree that it is valid. It is in this form of trust that initiatives such as Bitcoin excels. By contrast, Bitcoin performs poorly when it comes to the second notion of trust. Private cryptocurrencies appear to relate to the light-shaded part of the box in Figure 6 (rather than to 


\section{Ml Macrothink}

Business and Economic Research

ISSN 2162-4860

2019, Vol. 9, No. 4

the full box that covers both notions of trust). Whether one can exist without the other is difficult to say. A recent speech by the General Manager of the BIS casts some doubts in this regard, with Carstens (2019) arguing that "money and payment systems together make up the monetary system, and should be seen as two parts of the same whole." In fact, CMF discussions in April 2019 concluded that it is difficult, although perhaps not impossible, to conceive a pure payment system that is widely accepted and exists independently from a monetary system.

As to the second notion of trust, there are institutions, laws and rules designed and/or enforced by the state that make sure that an implicit contract between the individual and society is respected, which underlies the usefulness of money. That implicit contract is as follows. The individual generates value for someone else and receives in exchange a token that the individual trusts it can use in the future to obtain something else of equal value (Figure 6). In the current monetary system, that token takes the form of central bank reserves, cash and bank deposits. The latter are backed by the financial safety net, while central bank reserves and cash are directly backed by the sovereigns' power to tax. Moreover, supply of this type of token can be adapted to the demand for it, and that is what central banks do.

So far, the observed price volatility of cryptocurrencies, certainly of those with the currently largest market capitalizations, poses a serious barrier for them to be used as a medium of exchange or store of value. Stablecoins promise to address this issue, however. They are very heterogeneous and each initiative has a unique operational, governance and legal set-up, and each type of stablecoin raises some different issues. Preliminary discussions by the CMF's $A d$ Hoc Experts Group on Finance and Digitalisation in April 2019 suggest that an ideal stablecoin does not yet seem to exist, with experimentation continuing. Another observation is that what appear to be the more credible initiatives rely on deposits at insured banks as collateral, thus again implying some FSN elements.

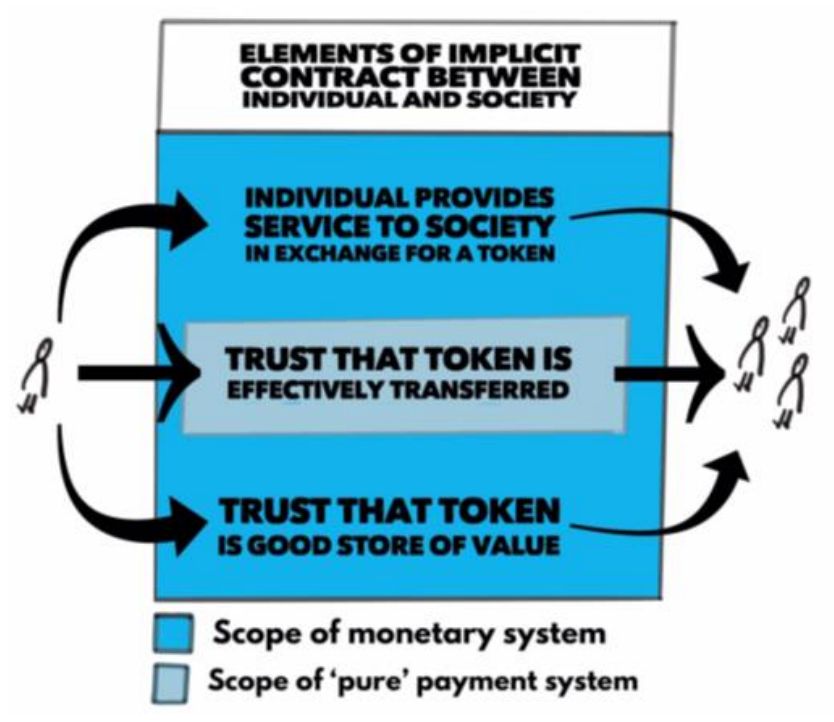

Figure 6. Stylised depiction of current implicit contract between individual and society Source: Author's assessment. 


\subsection{A Timely Opportunity Nonetheless to Reflect on the Current Monetary System}

Various proposals have been made to reconsider the current monetary system. Some proposals, such as forms of narrow-banking, are intended to reduce risks in the banking system by changing the organisational structures of individual banks or limiting the types of activities in which banks are allowed to participate. Such reforms would not, however, alter the basic nature of the fractional reserve system.

As pointed out by Rogoff (2016), the history of currencies shows that the private sector often innovates, but that the government regulates in due time. Regulation is important in order to ascribe cryptocurrencies with a clear and stable legal status. To the extent that cryptocurrencies are prevented from being redeemable or convertible to fiat currency, however, their economic value is compromised. Thus, until a clear regulatory framework clarifying their relationship to fiat currencies is in place, it will be difficult for any type of cryptocurrency to be widely used as money. ${ }^{6}$

Another scenario would be issuance of public cryptocurrency, that is, central bank digital or cryptocurrencies, which could be legal tender (Mancini-Griffoli et al., 2018). Many central banks are currently studying the possibility of such issuance. Based on a global survey among BIS member central banks, Barontini and Holden (2019) report that many central banks have studied central bank digital currency issuance, but only a very few have moved to consider practical issues, while "only a couple of central banks with idiosyncratic circumstances might issue a digital currency in the short or medium term." Some announced that they are exploring or experimenting with distributed ledger technology.

Conceptually, the fractional reserve system would be disrupted by the issuance of a CBDC. Banks would not be able to lend out more than they held in liquid deposits. They would need to become "loanable funds intermediaries", borrowing long-term funds to finance long-term investments. In fact, the fractional reserve system would be replaced by a narrow-banking system administered mainly by the central bank. Conceptually, the latter would be able to limit excessive leverage, maturity mismatches and the potential for bank runs. As a result, a FSN would not be needed. ${ }^{7}$ Thus far, the odds of this happening anytime in the near term seem remote, although, if it did, the implications for the "specialness" of the banking system could be profound.

Other monetary system solutions are being explored. For example, in Switzerland, a popular

\footnotetext{
${ }^{6}$ Cryptocurrencies could be regulated directly or indirectly, by focusing on the links created through exchanges between cryptocurrency and fiat currency. International regulatory approaches to cryptocurrencies and cryptoassets more generally differ widely and are being reviewed by the European Security and Markets Authority (ESMA) and the International Organisation of Securities Commission (IOSCO).

7 Alternatives to such a system are feasible in which a FSN might be needed. For example, central banks could lend back to banks the deposits that moved into CBDC. Or, non-banks could held deposits at banks, while payments between non-banks could be settled in CBDC. To the extent that banks could lend-on deposits at longer maturities, an important justification for the need for a FSN would still exist. Even in the extreme case of central banks issuing CBDC with deposit attributes and the public massively adopt it, banks could continue to have a role in distributing credit and creating liquidity. In such a scenario, they might become more dependent on central bank refinancing (Pfister, 2017), which necessitates a pre-announced rule-based lender-of-last-resort policy in order to limit moral hazard considerations (Pfister and Valla, 2018).
} 
referendum on a proposal to make the Swiss National Bank the sole issuer of money and end the traditional system was rejected in June 2018. Over $75 \%$ of Swiss voters rejected the Initiative "For crisis-resistant money: end fractional-reserve banking (Vollgeld)". The proposal contained several elements. Financial institutions could manage transactional accounts for customers but must hold equivalent assets with the Swiss National Bank (SNB). Commercial banks would have been prevented from "creating" money when issuing loans, thus effectively ending fractional reserve banking, under which only a fraction of deposits held by banks on behalf of customers are backed by notes and coins or banks' deposits at central banks. ${ }^{8}$

\section{Concluding Remarks}

Banks have been consistently regarded over several decades as "special", although the specific reasons for this assessment have evolved over time. As noted in Section 5, previous discussions by the CMF concluded that banks are "special" not because of any specific economic function that they perform, but rather as a result of the combination of different functions that they perform (Lumpkin and Schich, 2019), which include: ${ }^{9}$

- First, taking deposits that are withdrawable on demand and at par.

- Second, providing liquidity to other entities, thus, given the first function, engaging in maturity transformation.

- Third, acting as conduit for the payment system and monetary policy transmission.

Many of the specific individual economic functions listed above are being provided by Fintech initiatives either separately or in rebundled form. That said, the unbundling logic does not seem to apply to the role of banks as part of monetary policy transmission. In fact, the CMF discussion concluded that the privileged access of banks to the FSN is warranted especially by two observations.

- First, the risk of runs created by the combined provision of the first and second function, implying a crucial role of banks in maturity transformation.

- Second, the need to ensure the integrity of the transmission mechanism of monetary policy, in which incumbent banks play a crucial role. By contrast, the various Fintech entities perform a variety of financial services including payment services, but they do not play an active role in the transmission of monetary policy.

Fintech initiatives might gain access to selected safety net components, but these components will likely exclude access to the central bank balance sheet and the lender-of-last-resort function. Moreover, as they are currently not sufficiently systemically important, they would also not be expected to have access to the (non-explicit) guarantor-of-last resort function,

\footnotetext{
${ }^{8}$ The underlying idea, essentially a variation of the concept of narrow banking, often associated with Litan (1987), is summarized in Todd (2009).

${ }^{9}$ Banks' performance of each of these functions is challenged to some extent by Fintech initiatives. The degree to which the latter present competitive challenges differs from one specific function to another, although one needs to note that banks as institutions are also part of these developments, e.g. collaborating with or owning/buying Fintech initiatives.
} 
which was de facto added to the traditional safety net during the recent episode of systemic financial stress.

At the most fundamental level, banks as a group are special because central banks make them special. Central banks rely on the capacity of the banking system to create money and provide the economy with adequate liquidity, and consider the current system efficient. The privileged role of bank in these areas owe to current policy decisions and legislation that determine the nature of the current system of financial intermediation, which currently implies that sight deposits held by commercial banks with the central bank can be used for the settlement of payment transactions.

The government has the privilege to specify the means of payment in which tax settlement are accepted and this choice is a powerful tool to create incentives to use that means of payment in other transactions (as the recipients have the confidence to use the proceeds for tax payments), provided it maintains its purchasing power. This observation might explain why, so far, private cryptocurrencies have been used somewhat more widely only in jurisdictions with very high inflation. By contrast, if private cryptocurrencies were to become widely adopted, this situation would constitute a radical departure from the current system of financial intermediation, with significant implications for bank "specialness". In fact, private cryptocurrencies have been introduced with the explicit intent to disintermediate banks. The odds of such initiatives succeeding in that respect over the near term seem to be limited, however.

\section{References}

Adrian, T., \& Ashcraft, A. B. (2016). Shadow Banking: A Review of the Literature. Banking Crises, 282-315. UK: Palgrave Macmillan. https://doi.org/10.1057/9781137553799_29

Andolfatto, D. (2018). Assessing the Impact of Central Bank Digital Currency on Private Banks (mimeo). Federal Reserve Bank of St. Louis. 7 October.

https://doi.org/10.20955/wp.2018.025

Auer, R. (2019). Beyond the Doomsday Economics of "Proof-of-work" in Crypto-currencies". BIS Working Papers, 765. Monetary and Economic Department, Bank for International Settlements (BIS). https://doi.org/10.24149/gwp355

Barontini, C., \& Holden, H. (2019). Proceeding with Caution - A Survey on Central Bank Digital Currency. BIS Working Papers, 101. Monetary and Economic Department, Bank for International Settlements (BIS).

Beaudemoulin, N., Bienvenu, P., \& Warzee, D. (2018). Survey on the Digital Revolution in the French Banking Sector. ACPR/Banque de France Analyses et Synthèses, 88, March.

Bech, M., \& Garratt, R. (2017). Central Bank Crypto-currencies. BIS Quarterly Review, September 2017. [Online] Available: https://www.bis.org/publ/qtrpdf/r_qt1709f.pdf

BIS (2018). Crypto-currencies: Looking Beyond the Hype. BIS Annual Economic Report 2018, Chapter V, 91-114. Bank for International Settlements (BIS). [Online] Available: 
https://www.bis.org/publ/arpdf/ar2018e5.pdf

Blanchard, O. J., \& Fisher, S. (1989). Lectures on Macroeconomics. Cambridge: The MIT Press.

Borio, C. (2019). On Money, Debt, Trust and Central Banking. BIS Working Papers, 763. Monetary and Economic Department, Bank for International Settlements (BIS). [Online] Available: https://www.bis.org/publ/work763.pdf.

Calomiris, C. W. (1997). The Postmodern Bank Safety Net: Lessons from Developed and Developing Economies. The AEI Press, Publisher for the American Enterprise Institute. https://doi.org/10.3386/w5963

Calomiris, C. W., \& Wheelock, D. C. (1997). Was the Great Depression a Watershed in American Monetary History?. The Defining Moment. Michael Bordo, Claudia Goldin, \& Eugene White (eds.). Chicago: University of Chicago Press.

Carstens, A. (2019). The Future of Money and Payments. Speech given as 2019 Whitaker Lecture at the Central Bank of Ireland, Dublin, 22 March.

CBInsights (2019). 2019 Fintech Trends to Watch. [Online] Available: https://www.cbinsights.com/reports/CB-Insights_2019-Fintech-Trends-To-Watch-Briefing.pd f?utm_campaign=fintech_trends_2019-01\&utm_medium $=$ email\&_hsenc=p2ANqtz-8rPNqD VmXmkVsJTFaXBiWtxOCFmRpJGapfXKqPcpwnZEvxnsSO7BkidwBVEbILUKOHWxBs AksPtPasAnKoGmKguG1Dcg\&_hsmi=69491430\&utm_content=69491430\&utm_source=hs _automation\&hsCtaTracking=1ecebb20-e94c-45bc-b440-ddfb7bf0530c\%7C36fe 1654-0edf-4 51c-9fec-9fc3c2e00404

Claeys, G., Demertzis, M., \& Efstathiou, K. (2018). Crypto-currencies and Monetary Policy. Bruegel Policy Contribution, 10. [Online] Available:

http://bruegel.org/wp-content/uploads/2018/06/PC-10_2018_2.pdf

Corrigan, E. G. (1982). Are Banks Special?. Federal Reserve Bank of Minneapolis Annual Report (1-12).

Corrigan, E. G. (2000). Are Banks Special: A Re-visitation. The Region, Special Issue. Federal Reserve Bank of Minneapolis (1-4).

FSB/CGFS (Financial Stability Board and Committee on the Global Financial System) (2017). FinTech Credit - Market Structure, Business Models and Financial Stability Implications. Report prepared by a Working Group established by the Committee on the Global Financial System and the Financial Stability Board, 22 May 2017.

Havrylchyk, O. (2018). Regulatory framework for the loan-based crowdfunding platforms. OECD Economics Department Working Papers, 1513. Paris: OECD Publishing. https://doi.org/10.1787/24ad924a-enHavrylchyk.

He, D., Habermeier, K. F., Leckow, R. B., Haksar, V., Aleida, Y., ...Yepes, C. V. (2016). Virtual Currencies and Beyond: Initial Considerations. IMF Staff Discussions Note 16/3, 
Washington, DC: International Monetary Fund. https://doi.org/10.5089/9781498363273.006

Huertas, T. F. (2018). Are Banks Still Special?. Journal of Financial Perspectives, 5, 1. https://papers.ssrn.com/sol3/papers.cfm?abstract_id=3000194

IOSCO (2019). Issues, Risks and Regulatory Considerations Relating to Crypto-Asset Trading Platforms: Consultation Report. International Organisation of Securities Commission, May. [Online] Available: https://www.iosco.org/library/pubdocs/pdf/IOSCOPD627.pdf

Landau, J.-P. (with the collaboration of A. Genais) (2018). Les crypto-monnaies: Rapport au Ministre de l'Économie et des Finances, le 4 juillet 2018. French Ministry of Economy and Finance. [Online] Available:

https://www.mindfintech.fr/files/documents/Etudes/Landau_rapport_cryptomonnaies_2018.p df

Litan, R. E. (1987). What Should Banks Do?. Washington DC: Brookings Institution.

Lumpkin, S., \& Schich, S. (2019). Banks, Digital Banking Initiatives and the Financial Safety Net: Theory and Analytical Framework. OECD, mimeo.

Mancini-Griffoli, T., Martinez, P. M. S., Agur, I. et al. (2018). Casting Light on Central Bank Digital Currency. IMF Staff Discussion Note, November 2018. Washington DC: International Monetary Fund. https://doi.org/10.5089/9781484384572.006

Merton, R. C. (1995). A Functional Perspective of Financial Intermediation. Financial Management, 24:2, Silver Anniversary Commemoration, Summer 1995 (23-41). https://doi.org/10.2307/3665532

Pfister, C. (2017). Monetary Policy and Digital Currencies: Much Ado about Nothing?. Banque de France Working Paper 642. https://doi.org/10.2139/ssrn.3038906

Pfister, C., \& Valla, N. (2018). 'Nouvelle Normale' ou 'Nouvelle Orthodoxie': Éléments d'un nouveau cadre d'action pour les banques centrales. Banque de France Working Paper 680. https://doi.org/10.3917/reco.hs02.0041

Rogoff, K. (2016). The Curse of Cash. Princeton University Press. https://doi.org/10.1515/9781400883219

Schich, S. (2013). How to reduce implicit bank debt guarantees? A framework for discussing bank regulatory reform. Journal of Financial Regulation and Compliance, 21(4), 308-318. https://doi.org/10.1108/JFRC-03-2013-0006

Schich, S. (2018). Implicit Bank Debt Guarantees: Costs, Benefits, and Risks. Journal of Economic Surveys, 32(5), 1257-1291. https://doi.org/10.1111/joes.12287

Schwartz, A. J. (1992). The Misuse of the Fed's Discount Window. Federal Reserve Bank of St. Louis Review, 58-69. https://doi.org/10.20955/r.74.58-69

Smith, C., \& Kumar, A. (2018). Crypto-currencies - An Introduction to Not-so-funny Moneys. Journal of Economic Surveys. https://doi.org/10.1111/joes.12289 
Todd, W. (2009). Is This Risk Insurable? A Response to Sebastian Schich. Economics Discussion Paper 2009-21. https://doi.org/10.2139/ssrn.1726721

Werner, R. A. (2014). Can Banks Individually Create Money Out of Nothing? - The Theories and the Empirical Evidence. International Review of Financial Analysis, 36, 1-19.

https://doi.org/10.1016/j.irfa.2014.07.015

White, L. H. (2015). The Market for Cryptocurrencies. Cato Journal, 35(2), 383-402. [Online] Available: https://ideas.repec.org/a/cto/journl/v35y2015i2p383-402.html

Yermack, D. (2013). Is Bitcoin a Real Currency? An Economic Appraisal.

https://doi.org/10.3386/w19747

\section{Copyright Disclaimer}

Copyright for this article is retained by the author(s), with first publication rights granted to the journal.

This is an open-access article distributed under the terms and conditions of the Creative Commons Attribution license (http://creativecommons.org/licenses/by/3.0/). 